\title{
Efficacy of conventional ultrasound therapy on myofascial pain syndrome: a placebo controlled study
}

\author{
Miyofasiyal ağrı sendromunda konvansiyonel ultrason tedavisinin etkinliği: \\ Plasebo kontrollü çalışma
}

\author{
Gülis KAVADAR, ${ }^{1}$ Nil ÇAĞLAR, ${ }^{2}$ Şeyma ÖZEN, ${ }^{3}$ Şule TÜTÜN,,${ }^{2}$ Demet DEMIRCioĞLU ${ }^{4}$
}

\begin{abstract}
Summary
Objectives: Myofascial pain syndrome (MPS) is a complex pain syndrome characterized with trigger points (TP) in skeletal muscles. We aimed to assess the efficacy of ultrasound (US) therapy, which is one of the main devices used in physical medicine and rehabilitation, for the treatment of TP in MPS.

Methods: Fifty nine patients (49 females, 10 males) with active TP on the upper trapezius fibers were randomized into the treatment $(n=30)$ and the control groups $(n=29)$. The treatment group received conventional US therapy for 6 minutes, on 1.5 Watt $/ \mathrm{cm}^{2}$ dose with $1 \mathrm{MHz}$ frequency for 15 days whereas a placebo US therapy was administered to the control group. Prior to the treatment, immediately and 3 months later pain severity during rest and physical activity was assessed with visual analog scale (VAS), TP tenderness was measured with 0-5 scale, pressure pain threshold (PPT) was analyzed with algometer and the depression level was evaluated with Beck's depression questionnaire (BDP) by a clinician blinded to the groups.

Results: The mean age of the patients were $37.43 \pm 9.07$ and $35.83 \pm 5.68$ years, in the treatment and control groups, respectively. Compared to the pre-treatment values VAS, $0-5$ scale and BDP scores decreased $(p<0.01)$ along with an increase in PPT $(p<0.01)$ in both groups at the follow-up visits. $0-5$ scales and BDP scores were significantly lower and PPT was significantly higher in the treatment group, compared to the control group $(p<0.001)$.
\end{abstract}

Conclusion: Our results revealed that US treatment is effective on MPS.

Keywords: Myofascial pain syndrome; placebo ultrasound; ultrasound.

\begin{abstract}
Özet
Amaç: Miyofasiyal ağrı sendromu (MFAS), çizgili kas içinde tetik noktalar ile karakterize bir kompleks ağrı sendromudur. Çaıışmamızda, fizik tedavide kullanılan temel cihazlardan biri olan ultrasonun (US) tetik nokta tedavisindeki etkinliği araştırıldı.

Gereç ve Yöntem: Trapez kası üst liflerinde saptanan tetik noktalara bağlı MFAS tanııı konulan 59 hasta (49 kadın, 10 erkek) randomize olarak tedavi $(n=30)$ ve kontrol grubu $(n=29)$ olarak iki gruba ayrıldı. Tedavi grubuna 15 gün boyunca, günde bir kez 6 dakika süreyle $1.5 \mathrm{Watt} / \mathrm{cm}^{2}$ dozunda, $1 \mathrm{MHz}$ devamlı konvansiyonel US tedavisi, kontrol grubuna ise aynı sürede plasebo US tedavisi uygulandı. Tedavi öncesi, tedavi sonrası ve tedaviden üç ay sonra vizüel analog skala ile olguların istirahat ve aktivite sırasındaki ağrı düzeyi, sıfır-beş skalası ile tetik nokta hassasiyeti, algometre ile tetik nokta üzerindeki basınç ağrı eşiği ve Beck depresyon ölçeği ile depresyon düzeyleri, tedavi grubunu bilmeyen bir klinisyen tarafından değerlendirildi.

Bulgular: Olguların yaş ortalaması tedavi grubunda 37.43 \pm 9.07 , kontrol grubunda $35.83 \pm 5.68$ idi. Tedavi öncesi değerlerle karşılaştıııldığında, tedaviden sonra ve üç ay sonraki kontrollerde her iki grupta da ağı yakınmaları, tetik nokta hassasiyeti ve depresyon düzeyinde anlamlı bir azalma $(p<0.01)$, basınç ağrı eşiğinde anlamlı artış $(p<0.01)$ saptanmakla birlikte, grupların birbiriyle karşılaştııımasında ağrı, tetik nokta hassasiyeti ve depresyon düzeyindeki azalma ile basınç ağrı eşiğindeki artışın tedavi grubunda kontrol grubuna göre anlamlı derecede daha yüksek olduğu görüldü ( $p<0.001)$.
\end{abstract}

Sonuç: Sonuçlarımız, US tedavisinin miyofasiyal ağrı sendromlu olguların tedavisinde etkili olduğunu göstermektedir.

Anahtar sözcükler: Miyofasiyal ağrı sendromu; plasebo ultrason; ultrason.

'Department of Physical Therapy and Rehabilitation, Gunesli Medicine Hospital, i̇stanbul, Turkey

${ }^{2}$ Department of Physical Therapy and Rehabilitation, İstanbul Training and Research Hospital, İstanbul, Turkey

${ }^{3}$ Department of Physical Therapy and Rehabilitation, Kanuni Training and Research Hospital, İstanbul, Turkey

${ }^{4}$ Department of Physical Therapy and Rehabilitation, Memorial Hospital, İstanbul, Turkey

Submitted: 15.10.2014 Accepted after revision: 14.07.2015

Correspondence: Dr. Gülis Kavadar. Güneşli Medicine Hastanesi, Fizik Tedavi ve Rehabilitasyon Kliniği, İstanbul, Turkey.

Tel: +90 - 212 - 4890800 e-mail: gulisd@hotmail.com

C 2015 Turkish Society of Algology 


\section{Introduction}

Myofascial pain syndrome (MPS) is a syndrome characterized with pain and accompanying muscle spasm, refferred pain patterns, stiffness, restricted range of motion caused by trigger points on constricted fibers of muscles and/or fasciae. ${ }^{[1,2]}$ MPS is the most common reason of back pain, shoulder pain, tension type headache and regional pains such as facial pain. ${ }^{[2]}$ There is variation in the methodology for diagnosis of trigger points and a dearth of theory to explain how they arise and why they produce specific patterns of referred pain. ${ }^{[3]}$ Although mechanical, nociceptive and genetic pathologies and primary muscle dysfunctions are suggested to play a role in the pathogenesis of MPS, the exact mechanisms have not been elucidated yet. ${ }^{[4-6]}$ The main goal of MPS treatment is to break down the vicious circle of "spasm-painspasm" and release of trigger points. Various physical therapy modalities such as trigger point injection, stretching-spray technique or ultrasound (US), heat packs and TENS are used for the treatment of MPS. These modalities inactivate the trigger point with their thermal and/or mechanical effects. ${ }^{[7]}$

US is one of the most commonly used therapies for the treatment of MPS. Generation of heat is the most important and best-known effect of US. The thermogenic effect of US results in a transient increase in the flexibility of dense collagenous structures such as tendons, ligaments and joint capsules, which consequently decreases the stiffness of the joint, pain and accompanying muscle spasm and increases the blood flow temporarily. ${ }^{[8]}$ Besides, non-thermal effects are known to yield physiological effects and segmental analgesia. Reduction in muscular hyperalgia may be followed by decreased nociceptive input to the central nervous system and, as a consequence, central and peripheral sensitization are decreased. ${ }^{\left[{ }^{9]}\right.}$

The purpose of this study was to assess the efficacy of US therapy, which is one of the main devices used in physical rehabilitation, for the treatment of trigger points.

\section{Materials and Methods}

The study has been told to 140 patients younger than 50 years of age complaining of neck and/or back pain for a duration of shorter than 6 weeks, with palpable stiff fibers and active trigger points on the upper part of unilateral trapezius muscle. The diagnostic criteria of Travell and Simons were used for the diagnosis of MPS (Table 1). ${ }^{[7]}$

Patients with degenerative disorders, cervical disc hernia and fibromyalgia that might cause pain were excluded along with MPS patients who received any therapy within the previous 6 months. In addition, heavy workers, patients who were doing regular physical exercises, who had any systemic diseases, who had undergone neck or shoulder surgery and had any contraindication for US therapy were also excluded.

To evaluate the effectiveness of ultrasound monotherapy over miyofascial trigger points, the patients have been told that this was a research study and that in addition to thermal effect of ultrasound, massage effect could also be useful. Seventy two patients who accepted to be volunteers were included in the study.

Table 1. MPS diagnostic criteria

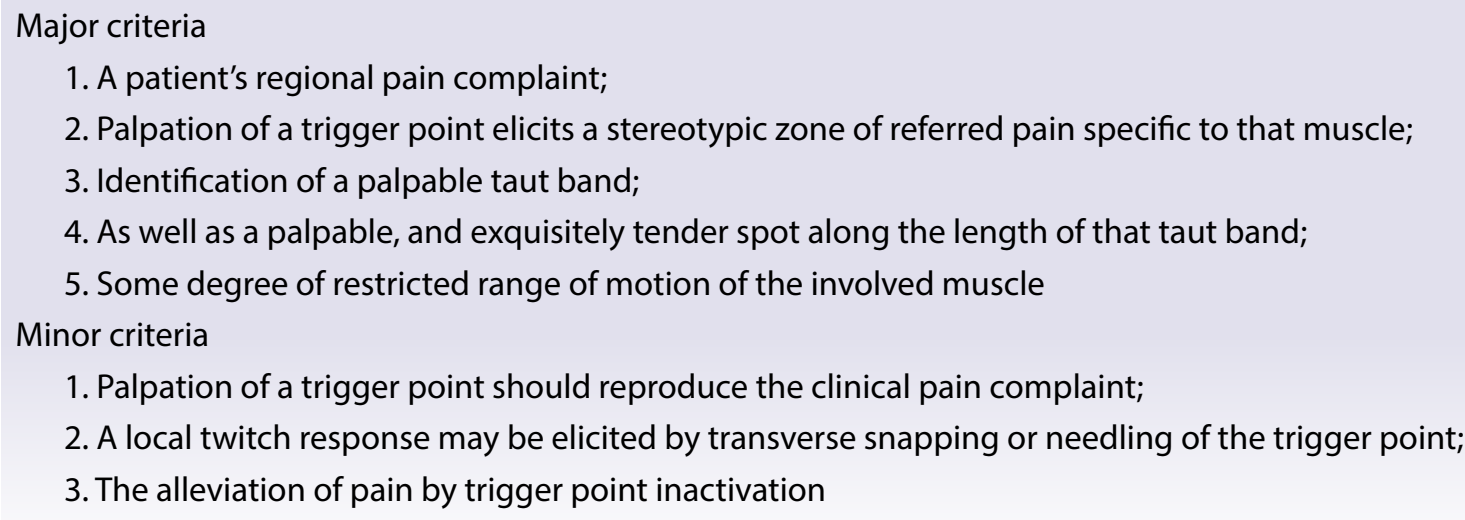

MPS: Myofascial pain syndrome. All of the five major criteria and at least one of the minor criteria are necessary for the diagnosis of MPS. 
Informed consent of the patients was obtained prior to the enrollment. The study protocol has been approved by the Hospital's Ethics Committee.

The patients were randomized with opaque sealed envelope technique into the US treatment and the control groups. The US therapy (C-Soundmaster GU001) was applied onto the trigger points with circular motions, each of which was completed in 1-2 seconds, with a US probe that had a $5 \mathrm{~cm}^{2}$ surface area. The continuous conventional US therapy was administered for 6 minutes every day, for a total of 15 sessions with a dose of $1.5 \mathrm{Watt} / \mathrm{cm}^{2}$ and $1 \mathrm{MHz}$ frequency. The same protocol was applied to the control group by the same clinician while the US device was turned off.

Patients were evaluated by a physician blinded to the groups, prior to the treatment, and immediately and 3 months after the treatment. The patients did not receive any analgesic medication except paracetamol as needed during the study period. The patients were seen at the outpatient clinic regularly, except the evaluations, and the subjects whose symptoms did not reduce with paracetamol and who needed other therapies were excluded from the study.

Six patients from the treatment group and 7 patients from the placebo group could not complete the study period. The study has been completed with 59 patients; 30 patients in the treatment group and 29 patients in the control group (Figure 1).

The pain severity during rest and physical activity was assessed with a visual analog scale (VAS), trigger point tenderness was measured with a scale of $0-5$, pressure pain threshold over the trigger points was analyzed with an algometer and level of depression was evaluated with Beck's depression questionnaire (BDQ).

VAS assessment was done with numbers from " 0 " to "10", placed on a $10 \mathrm{~cm}$ line. The patients were explained that " 0 " meant there was no pain, " 5 " moderate pain and " 10 " unbearable pain, and asked to mark the appropriate score on the line for their own pain during rest and physical activity. ${ }^{[10]}$

A scale of $0-5$, which is used in the measurement of localized pain such as trigger point, was administered as follows: 0 : no pain, 1: pain with profound palpation, 2: pain during superficial palpation, 3: painful fascial expressions with palpation, 4: startle response with palpation, 5: avoidance reflex with palpation. ${ }^{[11]}$

The level of pressure at the time when patients felt pain was recorded with an algometer device in terms of $\mathrm{kg} / \mathrm{cm}^{2}$. The measurements were performed 3 times with the intervals of 60 seconds and the mean value was recorded as pressure pain threshold. ${ }^{[12]}$

The BDQ form, which has been validated by Tegin et al. was used in this study. ${ }^{[13]}$

Statistical Package for Social Sciences (SPSS) for Windows program was used for analyzing the results. In addition to the descriptive statistical methods (mean, standard deviation), Student's t-test was used for the comparison of normally distributed variables, whereas non-normally distributed variables were compared with Mann-Whitney $U$ test. The efficacy of US treatment in each group was assessed with paired t-test, Wilcoxon Rank test and Fisher exact test. Qualitative variables of the groups were compared with chi-square test. Statistical significance level was set as $p<0.05$.

\section{Results}

Of the 59 patients included, 49 were females $(83.05 \%)$ and 10 were males (16.9\%). The mean age of the patients were $37.43 \pm 9.07$ and $35.83 \pm 5.68$ years in the treatment and control groups, respectively. Of women $61.22 \%$ (30) were housewifes, $28.57 \%$ (14) were desk workers, $10.20 \%$ (5) were medical personnels. Of men $70 \%$ (7) were desk workers, $20 \%$ (2) were unemployed, $10 \%$ (1) was tradesman.

No statistically significant difference was detected between the two groups in terms of sex, age, body mass index (BMI) and the duration of pain ( $p>0.05$ ) (Table 2).

Furthermore, the pre-treatment VAS during rest and physical activity, $0-5$ scale, algometer findings and $\mathrm{BDQ}$ values were similar between the two groups ( $p>0.05$ ) (Table 3).

Compared to the pre-treatment values pain severity, trigger point tenderness and level of depression de- 


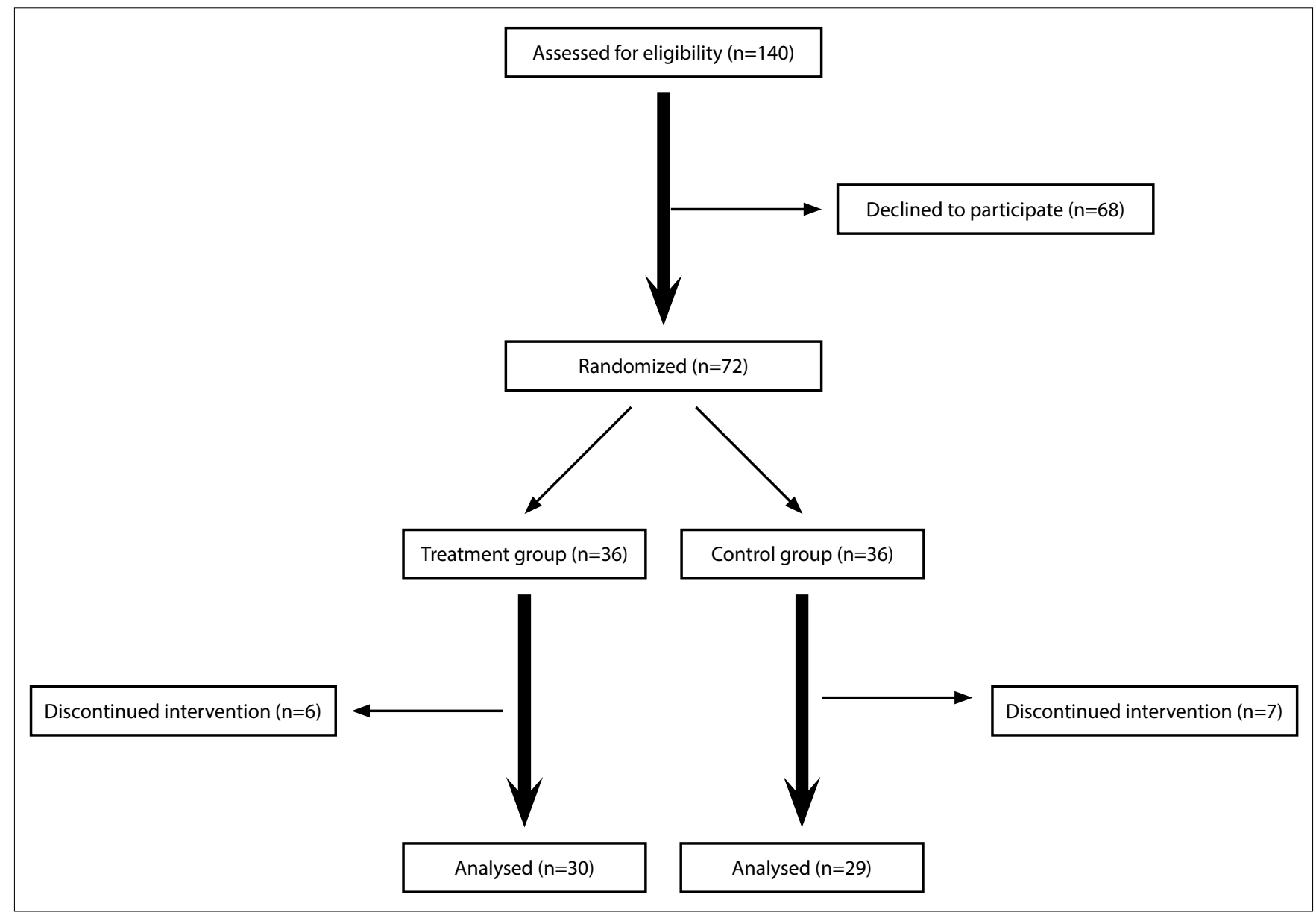

Figure 1. Flow diagram of enrollment.

creased $(p<0.01)$ along with an increase in pressure pain threshold $(p<0.01)$ in both groups at follow-up visits right after and 3 months after the treatment. However, VAS during rest and physical activity and 0-5 scale values were significantly higher, and pressure pain threshold was significantly lower in the placebo group, compared to the treatment group at follow-up visits immediately and 3 months after the treatment $(p<0.001)$ (Table 3$)$.

\section{Discussion}

This study demonstrated that US therapy, which is one of the main devices used in MPS treatment, has a significant impact on recovery.

In similar placebo-controlled studies which evaluated the efficacy of US for the treatment of MPS, Pillay et al..$^{[14]}$ and Ilter et al. ${ }^{[15]}$ demonstrated that both treatment forms of US, pulsed or continous, is superior to placebo whereas Draper et al. ${ }^{[16]}$ reported that US therapy decreases the tenderness of latent trigger points. In their study, which included 44 patients who had active trigger points on right trapezius muscle, Srbely and Dickey ${ }^{[17]}$ applied a single session of $1 \mathrm{Watt} / \mathrm{cm}^{2}, 1 \mathrm{MHz}$ continous US therapy for $5 \mathrm{~min}$ utes to the study group whereas control patients received placebo US treatment for the same duration of time and frequency. Trigger point tenderness was measured with algometer prior to and just after US treatment. The treatment group and control group had $44.1 \%$ and $1.4 \%$ improvement, respectively. Trigger point tenderness was also evaluated with algometer before and after 15 sessions of US treatment in the present study. The improvement rates in the treatment and placebo arms were found to be $38 \%$ and $10.44 \%$, respectively.

Although US is a commonly used device for physical therapy and rehabilitation, an article which reviewed 35 randomized, controlled studies and a systematic review including 38 studies reported that there is not enough evidence to support that US therapy is more effective than placebo in the treatment of musculoskeletal problems. ${ }^{[18,19]}$ Some review articles also highlight the conflicts regarding the efficacy of 
Table 2. Data regarding sex, age, body-mass index (BMI) and duration of pain in both groups

\begin{tabular}{|c|c|c|c|c|c|c|c|}
\hline & \multicolumn{3}{|c|}{ US group $(n=30)$} & \multicolumn{3}{|c|}{ Placebo group $(n=29)$} & \multirow[t]{2}{*}{$\mathbf{p}$} \\
\hline & $\mathbf{n}$ & $\%$ & Mean \pm SD & $\mathbf{n}$ & $\%$ & Mean \pm SD & \\
\hline \multicolumn{8}{|l|}{ Sex } \\
\hline Female & 24 & 80 & & 25 & 86.2 & & 731 \\
\hline Male & 6 & 20 & & 4 & 13.8 & & \\
\hline Age (years) & & & $37.43 \pm 9.07$ & & & $35.83 \pm 5.68$ & 0.420 \\
\hline $\mathrm{BMI}\left(\mathrm{kg} / \mathrm{m}^{2}\right)$ & & & $23.94 \pm 3.32$ & & & $25.18 \pm 4.36$ & 0.224 \\
\hline Pain duration (weeks) & & & $3.10 \pm 2.48$ & & & $3.18 \pm 2.72$ & 0.911 \\
\hline
\end{tabular}

US: Ultrasound; SD: Standard deviation.

US therapy. ${ }^{[20]}$ However, the dose of the US applied, treatment duration, the area and type of the treated tissue vary in most of the studies reviewed. In their meta-analysis and systematic review, Robertson ${ }^{[18]}$ and $\mathrm{Gam}^{[21]}$ stated that comparison of the study results is complicated due to the technical differences and combination of US therapy with other treatment types in several studies.

In order to achieve a therapeutic effect, the temperature of the tissue must be maintained around 40$45^{\circ} \mathrm{C}$ for at least 5 minutes. The response of the tissue is influenced from many factors such as frequency and density of US application, area of the probe, treatment frequency and duration. In our study continuous conventional US therapy, which was applied once a day for 6 minutes, with a $5 \mathrm{~cm}^{2}$ US probe at 1.5 Watt $/ \mathrm{cm}^{2}$ dose and $1 \mathrm{MHz}$ frequency, was found to be effective in the treatment of trigger points and no additional therapies were applied.

The improvement observed in the placebo group may be due to the compression and massage effect of the US probe, considering the previously reported efficacy of the compression and massage therapies applied on trigger points. ${ }^{[22]}$ Another possible explanation can be the non-specific treatment effects known as the placebo effects. These placebo effects can be related to the careful approach of the researcher towards the patient, the expectations of the patient from the treatment applied, the impact of interventions and treatment environment or meticulous observation of the patients because of the research experiments. Moreover, there are several publications, which demonstrated that placebo treatment decreases perception of pain by increas-
Table 3. Comparison of the VAS during rest and physical activity, 0-5 scale, algometer findings and $\mathrm{BDS}$ values between the two groups prior to the treatment, immediately and three months after the treatment

\begin{tabular}{|c|c|c|}
\hline & US group & Placebo group \\
\hline & Mean \pm SD & Mean \pm SD \\
\hline \multicolumn{3}{|l|}{ VAS-activity } \\
\hline Before treatment & $7.33 \pm 1.65$ & $7.00 \pm 1.41$ \\
\hline After treatment & $1.33 \pm 1.69$ & $5.10 \pm 1.42$ \\
\hline $3^{\text {rd }}$ month & $2.47 \pm 1.78$ & $6.21 \pm 1.47$ \\
\hline \multicolumn{3}{|l|}{ VAS-rest } \\
\hline Before treatment & $4.27 \pm 1.48$ & $4.55 \pm 1.15$ \\
\hline After treatment & $0.37 \pm 0.89$ & $2.28 \pm 1.39$ \\
\hline $3^{\text {rd }}$ month & $0.87 \pm 1.22$ & $3.72 \pm 1.16$ \\
\hline \multicolumn{3}{|l|}{$0-5$ scale } \\
\hline Before treatment & $3.63 \pm 1.00$ & $3.76 \pm 0.83$ \\
\hline After treatment & $0.57 \pm 0.77$ & $2.76 \pm 0.83$ \\
\hline $3^{\text {rd }}$ month & $1.17 \pm 0.79$ & $3.10 \pm 0.82$ \\
\hline \multicolumn{3}{|l|}{ Algometer } \\
\hline Before treatment & $7.40 \pm 1.00$ & $7.72 \pm 1.07$ \\
\hline After treatment & $10.27 \pm 0.94$ & $8.62 \pm 1.08$ \\
\hline $3^{\text {rd }}$ month & $9.63 \pm 1.16$ & $8.07 \pm 1.07$ \\
\hline \multicolumn{3}{|l|}{ BDS } \\
\hline Before treatment & $12.33 \pm 8.22$ & $10.97 \pm 5.91$ \\
\hline After treatment & $10.30 \pm 7.15$ & $10.17 \pm 5.79$ \\
\hline $3^{\text {rd }}$ month & $11.07 \pm 7.59$ & $10.69 \pm 6.40$ \\
\hline
\end{tabular}

VAS: Visual analog scale; US: Ultrasound; SD: Standard deviation.

ing the opioid levels in the circulation and it also has an anti-inflammatory effect due to elevated cortisol levels. ${ }^{[23-26]}$ The decrease in BDQ scores among patients none of which received any depression treat- 
ment indicates that chronic pain increases the depressive complaints in MPS patients. We believe that, the deterioration of the improved symptoms in both groups at the $3^{\text {rd }}$ month after the treatment is due to the exposure of the patients to micro and macro traumas during their daily lives which causes trigger point re-occurrence.

The analgesic effect of US therapy, which has been shown in numerous studies, may be explained with various mechanisms such as thermogenesis and metabolic changes. In the recent years, central sensitization mechanisms are thought to play a role in the physiopathology of MPS. ${ }^{[27,28]}$ The effect of US therapy on central pathways has also been evaluated. In their in vivo rat study, Hsieh et al. demonstrated the impact of therapeutic US on the central mechanisms of pain by demonstrating that US therapy modifies the number of dorsal horn neuronal nitric oxide synthase like neurons (nNOS-LI). Both nitric oxide (NO) and nitric oxide synthase (NOS) play role in the facilitation of central sensitization mechanisms and inflammatory hyperalgesia. With the effect of continuing nociceptive input, the number of nNOS-LI neurons increases in the spinal cord, which results in elevated NO and substance-P synthesis. ${ }^{[29]}$ US therapy decreases the pain by its impact on modulation of central neuronal pathways by this way. ${ }^{[30]}$

The effect of US on the trigger point tenderness has also been assessed when it is used in combination with exercise, injection, massage, manipulation and other treatment modalities. However, there are not sufficient data which demonstrate the direct effect of US therapy on trigger point tenderness and pain. Therefore, the findings of this study are important because of demonstrating the efficacy of US monotherapy on trigger point tenderness, pain and psychological state. The most important limitations of this study are its single-blind fashion and low patient number. In addition, we can not compare the paracetamol use between the two groups.

The suppression of the maintaining factors, posture training, stretching of the stiff and short muscles and exercise programs which strengthen the weak muscles are of major importance for providing long-term therapeutic effect in the treatment of MPS. In conclusion, this study demonstrates that US thera- py is effective in the treatment of MPS. However, further double-blind, randomized, placebo-controlled studies with specific US doses are required to provide further evidence regarding the efficacy of US on MPS treatment.

\section{Conflict-of-interest issues regarding the author- ship or article: None declared.}

\section{Peer-rewiew: Externally peer-reviewed.}

\section{References}

1. Stecco A, Gesi M, Stecco C, Stern R. Fascial components of the myofascial pain syndrome. Curr Pain Headache Rep 2013;17(8):352.

2. Jaeger B. Myofascial trigger point pain. Alpha Omegan. 2013;106(1-2):14-22.

3. Tough EA, White AR, Richards S, Campbell J. Variability of criteria used to diagnose myofascial trigger point pain syndrome--evidence from a review of the literature. Clin J Pain 2007;23(3):278-86.

4. Borg-Stein J, Simons DG. Focused review: myofascial pain Arch Phys Med Rehabil 2002;83(3 Suppl 1):40-9.

5. Pace MC, Mazzariello L, Passavanti MB, Sansone P, Barbarisi $M$, Aurilio C. Neurobiology of pain. J Cell Physiol 2006;209(1):8-12

6. Fernández-de-las-Peñas $C$, Dommerholt J. Myofascial trigger points: peripheral or central phenomenon? Curr Rheumatol Rep 2014;16(1):395.

7. Simons DG, Travell JG, Simons LS. Travell and Simons' Myofascial Pain and Dysfunction; the Trigger Point Manual. Vol. 1, 2 ed. Williams \& Wilkins, Baltimore 1999.

8. Unalan H, Majlesi J, Aydin FY, Palamar D. Comparison of high-power pain threshold ultrasound therapy with local injection in the treatment of active myofascial trigger points of the upper trapezius muscle. Arch Phys Med Rehabil 2011;92(4):657-62.

9. Gonçalves MC, Teixeira da Silva EG, Chaves TC, Dach F, Speciali JG. Static ultrasound and manual therapy in refractory migraine. Case report. Rev Dor. Sao Paulo 2012;13(1):80-4.

10. Dixon JS, Bird HA. Reproducibility along a $10 \mathrm{~cm}$ vertical visual analogue scale. Ann Rheum Dis 1981;40(1):87-9.

11. Treaster D, Marras WS, Burr D, Sheedy JE, Hart D. Myofascial trigger point development from visual and postural stressors during computer work. J Electromyogr Kinesiol 2006;16(2):115-24.

12. Fischer AA. Documentation of myofascial trigger points. Arch Phys Med Rehabil 1988;69(4):286-91.

13. Tegin B. Turkish version of Beck Depression Inventory. Unpublished Doctorate Thesis 1980.

14. Pillay GM.The treatment of myofascial pain syndrome using therapeutic ultrasound, on upper trapezius trigger points :a double-blinded placebo controlled study comparing the pulsed and continous waveforms of ultrasound. Dept. Chiropractic, Durban Institute of Technology 2003. 
15. Ilter L, Dilek B, Batmaz I, Ulu MA, Sariyildiz MA, Nas K, et al. Efficacy of Pulsed and Continuous Therapeutic Ultrasound in Myofascial Pain Syndrome: A Randomized Controlled Study. Am J Phys Med Rehabil 2015;94(7):547-54.

16. Draper DO, Mahaffey C, Kaiser D, Eggett D, Jarmin J. Thermal ultrasound decreases tissue stiffness of trigger points in upper trapezius muscles. Physiother Theory Pract 2010;26(3):167-72.

17. Srbely JZ, Dickey JP. Randomized controlled study of the antinociceptive effect of ultrasound on trigger point sensitivity: novel applications in myofascial therapy? Clin Rehabil 2007;21(5):411-7.

18. Robertson VJ, Baker KG. A review of therapeutic ultrasound: effectiveness studies. Phys Ther 2001;81(7):1339-50.

19. van der Windt DA, van der Heijden GJ, van den Berg SG, ter Riet G, de Winter AF, Bouter LM. Ultrasound therapy for musculoskeletal disorders: a systematic review. Pain 1999;81(3):257-71.

20. Hammer W, MS, DC. Therapeutic Ultrasound Effective for Musculoskeletal Problems. Dynamic Chiropractic 2011;26:29.

21. Gam AN, Johannsen F. Ultrasound therapy in musculoskeletal disorders: a meta-analysis. Pain 1995;63(1):85-91.

22. Kısaoglu S, Erdem HR, Goncu G, Yorgancioglu RZ. The effectiveness of ultrasound treatment in myofascial pain syndrome. Romatizma 2000;(2)15:123-7.

23. Clement Jones V, Rees LH. Neuroendocrine correlates of the endorphins and enkephalins. Int Clinical Neuroendocrinology 1982;2:139-209.

24. Fields HL, Levine JD. Placebo analgesia-a role for endorphins? Trends Neuro Sci 1984;7:271-3.

25. Kokkotou E, Conboy LA, Ziogas DC, Quilty MT, Kelley JM, Davis $\mathrm{RB}$, et al. Serum correlates of the placebo effect in irritable bowel syndrome. Neurogastroenterol Motil 2010;22(3):285-81.

26. Benedetti F, Mayberg HS, Wager TD, Stohler CS, Zubieta JK. Neurobiological mechanisms of the placebo effect. J Neurosci 2005;25(45):10390-402.

27. Simons DG, Mense S. Diagnosis and therapy of myofascial trigger points. [Article in German] Schmerz 2003;17(6):41924. [Abstract]

28. Woolf CJ. Central sensitization: implications for the diagnosis and treatment of pain. Pain 2011;152(3 Suppl):2-15.

29. Hsieh YL. Reduction in induced pain by ultrasound may be caused by altered expression of spinal neuronal nitric oxide synthase-producing neurons. Arch Phys Med Rehabil 2005;86(7):1311-7.

30. Kumar SP, Saha S. Mechanism-based Classification of Pain for Physical Therapy Management in Palliative care: A Clinical Commentary. Indian J Palliat Care 2011;17(1):80-6. 